\title{
Image-Enhanced Bronchoscopic Evaluation of Bronchial Mucosal Microvasculature in COPD [Corrigendum]
}

\author{
Metwally EM, Shafiek H, Morsi TS, et al. Int J Chron \\ Obstruct Pulmon Dis. 2016;11:2447-2455.
}

The first author, Eman Mahmoud Fathy, has advised the journal she wishes to change her name on the paper to Eman M Metwally. The original paper has been updated.

\section{Publish your work in this journal}

The International Journal of COPD is an international, peer-reviewed journal of therapeutics and pharmacology focusing on concise rapid reporting of clinical studies and reviews in COPD. Special focus is given to the pathophysiological processes underlying the disease, intervention programs, patient focused education, and self management protocols. This journal is indexed on PubMed Central, MedLine and CAS. The manuscript management system is completely online and includes a very quick and fair peer-review system, which is all easy to use. Visit http://www.dovepress.com/testimonials.php to read real quotes from published authors. 